\title{
Kepercayaan Rahab Berdasarkan Yosua 2:1-24
}

\section{Rahab's trust Based on Joshua 2: 1-24}

\author{
Randy Frank Rouw)* \\ 1) Alumni Sekolah Tinggi Filsafat Jaffray \\ *)Penulis korespondensi: randyrouw@gmail.com
}

\begin{abstract}
Abstrak
Tujuan penulisan ini adalah membuktikan bahwa kepercayaan Rahab terwujud melalui setiap tindakan Rahab dalam Yosua 2:1-24. Penulis surat Ibrani dan Yakobus mengungkapkan bahwa setiap tindakan Rahab menunjukkan kepercayaannya kepada Allah, namun dalam narasi Yosua 2 tidak ada keterangan yang jelas apakah benar setiap tindakan Rahab mewujudkan kepercayaannya kepada Allah bangsa Israel. Sebagai kesimpulan, Rahab memang memiliki latar belakang non-Israel, namun hal itu tidak menutup anugerah keselamatan untuk dinikmatinya. Rahab membuktikan kesungguhannya untuk percaya dan berserah kepada Allah bangsa Israel melalui setiap tindakannya demi menolong umat Allah. Dalam meneliti narasi Yosua 2:1-24, penulis menggunakan prinsipprinsip umum dalam hermeneutik. Selain itu, penulis juga meneliti narasi Yosua 2 dengan menggunakan metode penafsiran narasi terkait genre dari Yosua 2:1-24 adalah narasi.
\end{abstract}

Kata Kunci: Allah, berbohong, kepercayaan, Rahab, tindakan, Yosua 2.

The purpose of this writing is to prove that Rahab's belief is manifested through every act of Rahab in Joshua 2: 1-24. The writers of Hebrews and James reveal that every act of Rahab shows her belief in God, but in Joshua's narrative there is no clear explanation of whether it is true that every act of Rahab embodies her belief in the God of Israel. Rahab does have a non-Israelite background, but that fact does not exclude her from the enjoyment of the grace of salvation. Rahab proves her sincerity to believe and surrender to the God of Israel through her every action to help the people of God.

Key words: God, lying, belief, Rahab, act, Joshua 2.

\section{Pendahuluan}

Awal mula nama "Rahab" muncul di Alkitab adalah dalam Kitab Yosua, tepatnya pasal 2. Alkitab dengan gamblang menerangkan bahwa Rahab adalah seorang perempuan sundal (Yosua 2:1). ${ }^{1}$ Selain statusnya

${ }^{1}$ Mariska Louterboom, "Pelacuran Suci: Konsep Pelacuran Menurut Kisah Perempuan Bernama Rahab dalam Yosua 2:1-24 sebagai bagian Sejarah Deuteronomis," 
yang adalah perempuan sundal, Rahab juga adalah perempuan Kanaan. Alkitab tidak mengupas secara jelas mengenai keberadaan Rahab. Tetapi dari teks Yosua 2, diketahui bahwa Rahab memiliki rumah di kota Yerikho. Ia tinggal di atas tembok kota Yerikho pada Zaman Perunggu Akhir. ${ }^{2}$ Dari keberadaannya di kota Yerikho ini saja dapat menunjukkan bahwa ia adalah seorang wanita dari bangsa Kanaan. ${ }^{3}$

Bangsa Kanaan merupakan salah satu dari sekian banyak bangsa yang hendak dimusnahkan Allah melalui bangsa Israel. Allah berjanji untuk membawa bangsa Israel ke tanah perjanjian, yaitu tanah Kanaan dan untuk itu bangsa Israel harus menaklukkan orang-orang Kanaan yang menempati tanah itu. Selain itu, ada alasan di balik perintah Allah untuk memusnahkan bangsa Kanaan yang berhubungan dengan kebudayaan dan agama Kanaan. Lasor, Hubbard dan Bush mengungkapkan demikian:

Bagi Allah, orang Kanaan benar-benar sangat berdosa. Mereka tidak hanya melakukan hal-hal yang sangat dibenci-Nya tetapi juga mencoba menjerat orang Israel untuk mengikuti kebiasaan agama mereka. Penemuan naskah Ugarit di Ras Syamra, Siria, telah memberi informasi yang terinci tentang kebiasaan agama Kanaan. Dalam suatu ceramah Albright pernah menyebut agama Kanaan sebagai agama yang paling bejat di antara agama-agama yang dikenal manusia karena kebiasaan-kebiasaannya seperti pelacuran di kuil, pengurbanan anak dan ciri-ciri lainnya. ${ }^{4}$

Dari kebudayaan dan agama mereka, bangsa Kanaan memanglah patut untuk memperoleh hukuman dari Allah. Kehidupan yang penuh dengan pelacuran, adanya pengorbanan anak-anak, praktek politeisme ${ }^{5}$ dan berbagai penyimpangan lainnya membuat mereka menjadi bangsa yang bejat dan tidak layak bagi Allah dan karena itu, pantaslah bangsa Kanaan dimusnahkan Allah. Namun, hal yang ajaib terjadi kepada sesosok perempuan Kanaan yang memperoleh keselamatan dari pemusnahan tersebut, yaitu Rahab. Dalam Yosua 6:25 diketahui bahwa pada akhirnya Rahab selamat dari serangan bangsa Israel. Menjadi sebuah keunikan tersendiri karena Rahab yang seharusnya dimusnahkan bersama dengan

Jurnal Kajian Sosial Interdisipliner Bina Darma 24, No. 72 (September 2006):209, diakses 12 Juni 2017, http://repository.uksw.edu/bitstream/

123456789/6181/2/ART_Mariska\%20Lauterboom_Pelacuran\%20Suci_fulltext.pdf

2J. D. Douglas, ed., Ensiklopedia Alkitab Masa Kini Jilid 2: M-Z (Jakarta: Yayasan

Komunikasi Bina Kasih, 1995), 289.

${ }^{3}$ Daniel Simamora, The Bible Who's Who: A Biblical Biography (Bandung: Cipta Olah Pustaka Publishing House, 2016), 942.

${ }^{4}$ W. S. Lasor, D. A. Hubbard, dan F. W. Bush, Pengantar Perjanjian Lama l: Taurat dan Sejarah (Jakarta: BPK Gunung Mulia, 1993), 292.

${ }^{5}$ R. K. Harrison, Old Testament Times (Michigan: William B. Eerdmans Publishing Company, 1979), 167. 
bangsanya, malah memperoleh keluputan dari kebinasaan. Ini dipercaya dapat dinikmati Rahab karena kepercayaannya kepada Allah bangsa Israel, yang ia akui adalah Allah di langit di atas dan di bumi di bawah (Yos. 2:11). Thomas Holdcroft juga mengungkapkan bahwa melalui Yosua 2 kepercayaan Rahab kepada Allah bangsa Israel dinyatakan. ${ }^{6}$

Dalam Surat Ibrani, penulis surat menuliskan bahwa keluputan Rahab dari ke binasaan adalah karena imannya. Dituliskan bahwa karena imannya, Rahab tidak turut binasa bersama orang-orang sebangsanya yang dipandang durhaka (Ibr. 1l:31). Namun yang menjadi pertanyaan adalah apa yang mendasari penulis Ibrani menyatakan bahwa Rahab selamat karena imannya sedangkan dalam narasi kisah Rahab dalam Yosua 2 tidak mencantumkan sedikitpun kata iman ataupun kepercayaan?

Penulis Ibrani sedikit menyinggung perwujudan iman dari Rahab, yaitu melalui tindakannya. Dalam Ibrani 1l, Rahab menunjukkan imannya dengan menyambut para pengintai yang diutus Yosua dengan baik (ay. 31). Selain itu, Yakobus juga mencatatkan bahwa Rahab dibenarkan karena perbuatannya yang menyembunyikan kedua pengintai dan membantu mereka lolos dari Yerikho (Yak. 2:25). Namun, kembali timbul pertanyaan, apakah benar bagian-bagian dalam Yosua 2 yang berkaitan dengan tindakan Rahab sungguh menunjukkan kepercayaannya kepada Tuhan Allah Israel? Salah satu tindakan yang menjadi permasalahan bagi para ahli Perjanjian Lama dan teolog adalah tentang kebohongan Rahab.

Yosua 2:3-4 dengan jelas menunjukkan akan kebohongan Rahab terhadap para utusan-utusan raja Yerikho. Ketika raja Yerikho mendengar kabar akan kedatangan pengintai-pengintai ke kotanya, ia segera mengutus para orang-orangnya untuk menemui Rahab. Raja tahu keberadaan kedua pengintai di rumah Rahab dan menghendaki Rahab segera menyerahkan mereka, tetapi Rahab menyembunyikan keberadaan kedua pengintai itu dan memberikan kesaksian yang palsu kepada para utusan raja. Melalui kebohongannya, Rahab menolong kedua pengintai dan beroleh selamat. Tapi, apakah melalui tindakan tidak jujur ini juga menyatakan kepercayaan Rahab?

Bakker mengungkapkan bahwa tindakan Rahab yang berbohong harus dicela. Perlindungan yang diberikan Rahab kepada para pengintai memang baik, tetapi cara melakukannya, yaitu dengan berbohong tidak patut ditiru. ${ }^{7}$ Berdasarkan tulisannya, bagi Bakker kebohongan Rahab

${ }^{6}$ Rahab memperlihatkan iman dan penyerahannya kepada Allah meskipun Alkitab secara khusus memperkenalkannya sebagai seorang perempuan sundal. L. Thomas Holdcroft, Kitab-Kitab Sejarah (Malang: Gandum Mas, 1996), 6.

${ }^{7}$ F. L. Bakker, Sejarah Kerajaan Allah 1: Perjanjian Lama (Jakarta: BPK Gunung Mulia, 2004), 393. 
tidak dapat ditoleransi dan ditiru. Ketidakjujuran Rahab patut dicela, meskipun untuk tujuan melindungi kedua pengintai.

Berbeda dengan yang tercantum di dalam The Bible Knowledge Commentary kalau kebohongan Rahab ini dapat ditolerasi dikarenakan ini merupakan masalah budaya. Rahab yang lahir dan tumbuh di antara orang-orang Kanaan, kemungkinan kebohongan menjadi suatu hal yang wajar. ${ }^{8}$ Demikian juga yang dicantumkan di dalam Alkitab Penuntun Hidup Berkelimpahan. Rahab bukanlah anggota masyarakat perjanjian dan tidak terikat dengan hukum-hukum moral perjanjian. ${ }^{9}$ Jadi, berdasarkan pandangan ini, tindakan Rahab yang berbohong dapat ditoleransi karena latar belakang budaya atau kebangsaan Rahab dan statusnya sebagai orang yang tinggal di luar hukum perjanjian sehingga belum mengenal hukum Allah. Namun, dari kedua pandangan ini semakin mengaburkan akan pendapat Thomas yang menyatakan Yosua 2 menyatakan kepercayaan Rahab. Selain itu, yang cukup menjadi permasalahan adalah cara Rahab mengetahui Allah, yaitu dengan mendengar.

Ketika dialog antara Rahab dengan kedua pengintai dimulai, Rahab mengakui bahwa ia tahu Tuhan telah menyerahkan bangsanya kepada bangsa Israel (Yos. 2:9). Di ayat 10, Rahab juga mengakui bahwa apa yang ia ketahui dan cara ia mengenal Tuhan adalah dengan "mendengar" akan perbuatan Allah yang dahsyat dan hal itu menimbulkan ketakutan dan kegentaran bagi dirinya dan segenap bangsa Kanaan (Yos. 2:9b,11). Namun, jika mengacu dengan perkataan Thomas, apakah hal ini merupakan kepercayaan yang sungguh-sungguh? Apakah hanya dengan mendengar saja dapat diputuskan bahwa itu merupakan wujud kepercayaannya kepada dengan Allah? Selain itu, hasil dari mendengar dan mengenal Allah adalah ketakutan dan kegentaran. Apakah Rahab percaya kepada Tuhan atau hanya sekedar takut dan gemetar mendengarkan perbuatan Tuhan? Melalui beberapa kasus dan permasalahan dalam teks membuat kepercayaan Rahab kepada Allah Israel menjadi kabur.

\section{Pembahasan Tentang Wujud Kepercayaan Rahab dalam Yosua 2:1-24}

\section{Rahab Menerima Kedua Pengintai (ay. l)}

Dalam Ibrani 11:31, tertulis Rahab menunjukkan imannya dengan menerima kedua pengintai. Di dalam narasi Yosua 2, kata "menerima" tidak ditemukan. Tetapi tindakan Rahab di ayat 1 menunjukkan sikap

${ }^{8}$ John F. Walvoord dan Roy B. Zuck, ed., The Bible Knowledge Commentary (United States of America: Victor Books, 1985), 331.

${ }^{9}$ Donald C. Stamps, ed., Alkitab Penuntun Hidup Berkelimpahan (Malang: Gandum Mas, 2010), 337. 
penerimaan tersebut. Sesampai kedua pengintai di Yerikho, mereka tiba di rumah Rahab. Setelah tiba di rumah Rahab, informasi yang diberikan hanya kedua pengintai tidur di rumah Rahab. Tindakan Rahab ini menunjukkan bahwa ia menerima kedua pengintai. Rahab mengijinkan kedua pengintai untuk tidur di rumahnya.

Penerimaan Rahab terhadap kedua pengintai merupakan permulaan wujud kepercayaan Rahab kepada Allah. Dia mulai menunjukkan keseriusannya untuk berserah kepada Tuhan Allah Israel dengan menerima kedua pengintai yang diutus oleh Yosua. Kepercayaan Rahab diwujudkan melalui kesetiaannya kepada umat Allah, dari menerima kedua pengintai sampai menolong mereka kabur dari Yerikho. ${ }^{10}$

\section{Rahab Melindungi Kedua Pengintai (ayat 2-7)}

Kata "melindungi" tidak terdapat di dalam ayat 2-7, bahkan tidak terdapat dalam keseluruhan Yosua 2. Tetapi, dari tindakan-tindakan Rahab di ayat 2-7 dapat terlihat bahwa Rahab sedang berusaha melindungi kedua pengintai dan tindakan Rahab merujuk kepada kepercayaannya terhadap Allah. Terdapat dua usaha Rahab untuk melindungi kedua pengintai di ayat 2-7, yaitu: Rahab menyembunyikan kedua pengintai (ay. 4a dan 6) dan Rahab berbohong kepada utusan raja (ay. 4b-5).

Tindakan pertama yang Rahab lakukan adalah membawa dan menyembunyikan kedua pengintai (ay. 4a dan 6). Kata dalam Bahasa Ibrani yang dipakai untuk menjelaskan tindakan Rahab adalah ח "wattiqakh" (bentuk imperfek feminim tunggal dari kata dasar "laqakh")

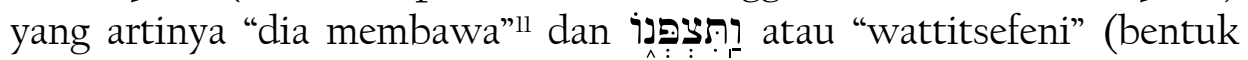
imperfek feminim tunggal dari "tsapan") yang artinya "dia menyembunyikan". ${ }^{2}$ Jadi, dari bagian ini diketahui bahwa saat itu Rahab membawa kedua pengintai dan menyembunyikan mereka.

Kata "membawa" memiliki kesamaan arti dengan kata "menyuruh" di dalam ayat 6. Kata "menyuruh" dipergunakan ketika Rahab membawa kedua pengintai ke atas sotoh rumahnya. ${ }^{13}$ Dalam ayat 6, kata "menyuruh" adalah הִיעדתם atau "he'elatam" dengan bentuk hifil perfek feminim orang

\footnotetext{
${ }^{10}$ David Gooding, An Unshakeable Kingdom (Michigan: William B. Eerdmans Publishing Company), 236.

${ }^{11}$ WTM Morphology, Word Analysis, In Bible Works Version 7, s.v. "ותח".

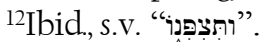

${ }^{13}$ Rumah pada zaman itu memiliki ciri-ciri beratap datar dan itu yang dinamakan sotoh. Biasanya, kegiatan-kegiatan rumah tangga sehari-hari dilakukan di sotoh rumah. Di sanalah Rahab menyembunyikan kedua pengintai. Leland Ryken, dkk., ed., Kamus Gambaran Alkitab: The Dictionary of Biblical Imagery (Surabaya: Momentum, 2011), s.v. "sotoh rumah".
} 
ke-3 tunggal dari kata dasar עָלָד atau "alah". Dalam konteks ayat 6, kata "menyuruh" lebih mendekati kepada arti "membawa", "menuntun" atau "menawarkan". .14 Jadi, tindakan Rahab saat itu bisa jadi membawa kedua pengintai dengan cara membujuk mereka untuk mengikuti instruksinya.

Dari kata "membawa" dan "menyuruh", dapat terlihat keaktifan Rahab untuk menolong. Tanpa adanya dorongan atau paksaan dari pihak pengintai, Rahab rela menolong. Rahab sendiri sepertinya yang memberikan tawaran untuk menolong mereka. Rahab pastinya sadar akan keadaan kedua pengintai yang terdesak, maka dari itu ia menawarkan pertolongan kepada dua pengintai tersebut.

Selain membawa kedua pengintai, Rahab juga menyembunyikan mereka. Kata "menyembunyikan" terdapat di dalam ayat 4a dan 6, namun masing-masing menggunakan kata Ibrani yang berbeda. Di ayat 4, kata yang dipakai adalah "menyembunyikan", "memberikan tempat perlindungan", dan "menyimpan". ${ }^{5}$ Sedangkan di ayat 6, kata yang dipergunakan adalah atau "taman" yang punya arti menyembunyikan. ${ }^{16}$ Masing-masing memiliki pengertian yang tidak jauh berbeda.

Di ayat 4 penulis kemungkinan ingin memberikan kesan tersendiri atas tindakan Rahab. Ketika Rahab menyembunyikan kedua pengintai, ia seolah-olah seperti sedang menyimpan sebuah benda yang sangat penting atau harta benda. Ketika seseorang memiliki barang yang sangat berharga, pasti benda tersebut akan dijaga, dilindungi dan disimpan dengan sangat hati-hati dan teliti. Demikian juga Rahab memperlakukan kedua pengintai. Kedua pengintai itu hendak Rahab jaga sungguh-sungguh bagaikan harta benda yang dimilikinya. Rahab tidak ingin kehilangan kedua pengintai. Rahab merasa butuh akan keberadaan kedua pengintai. Oleh sebab itu, penulis Kitab Yosua menggunakan kata "tsafan" di ayat 4.

Di dalam ayat 6 , kata yang dipakai berbeda karena penulis Kitab Yosua hanya hendak memberikan detail tindakan dari Rahab kepada pembaca. Di ayat 6, aktivitas Rahab secara detail dijelaskan bahwa saat itu ia sedang menyembunyikan kedua pengintai di bawah timbunan batang rami. ${ }^{17}$ Di ayat 4 penjelaskan akan tindakan "menyembunyikan" tidak terlalu banyak, namun di ayat 6 tindakan Rahab kembali diulangi dengan sedikit lebih lengkap. Rahab menyembunyikan kedua pengintai saat itu dengan menutupi mereka di bawah timbunan batang rami.

${ }^{14}$ WTM Morphology, Word Analysis, In Bible Works Version 7, s.v. "העיכלתים".

${ }^{15}$ Ibid., s.v. "פפַב"

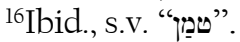

${ }^{17}$ Rami merupakan bahan yang dipergunakan untuk membuat lenan. Tingginya biasanya sekitar 1 meter. Sebelum dipakai, biasanya rami dijemur terlebih dahulu, seperti yang Rahab lakukan. Ia menyimpan batang raminya di sotoh rumah kemungkinan bertujuan untuk dijemur. Kamus Alkitab versi 1.2.1, s.v. "rami". 
Dalam bukunya, John mengungkapkan bahwa kata "menyembunyikan" di ayat 6 juga punya artian "mengubur". Jadi, ketika Rahab sedang menyembunyikan kedua pengintai di bawah timbunan rami, ia seperti sedang mengubur mereka. Rahab benar-benar menutupi seluruh tubuh kedua pengintai dengan tumpukan rami sehingga keberadaannya tidak diketahui. ${ }^{18}$ Inilah usaha awal yang Rahab lakukan.

Sebelum kedatangan para utusan raja, Rahab sudah terlebih dahulu menawarkan pertolongan dengan membawa mereka ke sotoh rumah dan menyembunyikan mereka. Rahab mulai memperlihatkan kesungguhannya untuk menolong kedua pengintai. Inisiatifnya untuk membawa dan melindungi pengintai serta usahanya untuk menyembunyikan mereka agar tidak diketahui oleh utusan-utusan raja menjadi bentuk kesungguhan Rahab dalam menolong kedua pengintai. Selain itu membawa dan menyembunyikan, tindakan lain yang tidak terlepas dari tindakan ini adalah Rahab berbohong.

Meskipun di dalam Yosua 2 tidak terdapat kata "berbohong", tapi dalam ayat 4b-5 Rahab memberikan kesaksian yang palsu. Bermula dari ayat 2, ada orang ${ }^{19}$ yang memberikan informasi akan keberadaan dua pengintai dari Israel ${ }^{20}$ kepada raja Yerikho. ${ }^{21}$ Kemudian, mendengar akan kabar tersebut, dengan segera raja menyampaikan pesan kepada Rahab. ${ }^{22}$ Raja Yerikho memerintahkan Rahab untuk membawa keluar ${ }^{23}$ pengintai-

${ }^{18}$ John D. Currid, Strong and Courageous: Joshua Simply Explained (England: EP Books, 2011), 36 .

${ }^{19}$ Ternyata kedua pengintai telah diamati sejak kedatangan mereka ke kota Yerikho yaitu pada malam hari (ay. 2). Keberadaan mereka sebagai orang Israel telah diketahui. Pelapor bahkan juga mengetahui tujuan kedatangan mereka. Ia tahu kalau kedua pengintai hendak menyelidiki negeri Kanaan. Namun, tidak ada informasi yang memadai tentang keberadaan si pelapor. Dari mana atau siapa si pelapor dan dari mana ia tahu status mereka sebagai orang Israel. Hal-hal ini tidaklah tertulis di dalam Alkitab dan tidak ada penjelasan yang pas untuk hal ini.

${ }^{20}$ Luas kota Yerikho hanyalah sekitar 3 hektar. Karena wilayahnya yang tidak terlalu luas untuk ukuran sebuah kota, informasi sangatlah cepat untuk diketahui oleh raja. Howard Clark Kee, dkk., ed., Alkitab Edisi Studi (Jakarta: Lembaga Alkitab Indonesia, 2015), 346.

${ }^{21}$ Kota-kota Kanaan tidaklah bergabung di bawah sebuah pemerintahan. Setiap wilayah kota mempunyai pemimpinnya sendiri. Kebanyakan bagian kota adalah kota bebas yang diperintah oleh seorang raja. Oleh sebab itu, raja - sebagai pemegang kuasa tertinggi - punya hak untuk mengetahui berbagai informasi yang penting di kotanya. Frank E. Gaebelein, The Expositor's Bible Commentary (Michigan: Zondervan Publishing House, 1992), 260.

${ }^{22}$ Dalam Bahasa Ibrani, tidak dicantumkan "raja menyuruh orang kepada Rahab". Yang tertulis adalah "raja mengirim kepada Rahab pesan" atau "raja mengirim kepada Rahab perkataan". WTM Morphology, Word Analysis, In Bible Works Version 7, Joshua 2:3.

${ }^{23}$ Kata yang dipakai untuk kata "membawa keluar" adalah konteks Yosua 2:3, kata yatsa memilik makna "menyerahkan". Jadi, yang raja Yerikho 
pengintai itu karena ia tahu tujuan kedua pengintai datang ke kotanya, yaitu untuk menyelidiki negeri Kanaan (ay. 3). Namun, Rahab berusaha melindungi kedua pengintai dengan membohongi orang utusan raja. ${ }^{24}$

Ketika Rahab menjawab pesan dari raja Yerikho, Rahab mengawalinya dengan berkata jujur. Rahab mengakui bahwa memang benar kedua pengintai itu telah datang ke rumahnya. Rahab berkata: "Memang, orang-orang itu telah datang kepadaku, ... Kata "memang" menunjukkan bahwa Rahab setuju dengan isi pesan raja. Kata "memang" punya kesamaan arti dengan benar dan iya. ${ }^{25}$ Selain itu, "orang-orang itu" mengacu kepada kedua pengintai. Kemudian, kata Ibrani untuk mengungkapkan kata "datang” adalah "bo'u” (쪾, bentuk qal perfek orang ke-3 jamak dari kata dasar "bo" atau בוֹאוֹ). Kata ini juga memiliki arti "masuk". Jadi, sesungguhnya Rahab saat itu mengakui atau menyetujui bahwa kedua pengintai telah datang atau masuk ke dalam rumahnya. ${ }^{26}$ Namun, jawaban Rahab tidaklah berhenti sampai di situ.

Jawaban Rahab berlanjut demikian: "tetapi aku tidak tahu dari mana mereka, dan ketika pintu gerbang hendak ditutup menjelang malam, maka keluarlah orang-orang itu; aku tidak tahu, ke mana orang-orang itu pergi. Segeralah kejar mereka, tentulah kamu dapat menyusul mereka (ay. 4b-5)." Dari bagian ini Rahab memulai kesaksian yang tidak benar. Pertama, Rahab berkata bahwa ia tidak tahu asal kedua pengintai. Kata "tahu" berasal dari kata דִ atau "yada" yang dapat berarti mengetahui, mengenal dan menyadari. ${ }^{27}$ Kata ini ditambah dengan partikel "lo" (לאו) atau "tidak" dan berubah menjadi "tidak mengetahui" atau "tidak menyadari" atau "tidak mengenal". ${ }^{28}$ Kemudian, kata selanjutnya adalah אַ atau "ayin" yang merupakan merujuk kepada kata tanya "dari mana" atau "di mana". ${ }^{29}$ Jadi, Rahab mengatakan bahwa dirinya tidak mengetahui atau menyadari dari mana kedua pengintai itu. Rahab memberitahukan bahwa ia tidak mengetahui

inginkan adalah Rahab menyerahkan para pengintai yang saat itu ada di dalam

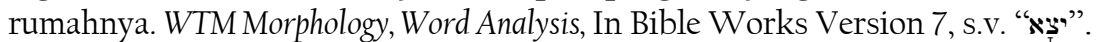

${ }^{24}$ Orang-orang yang diutus oleh raja Yerikho kemungkinan adalah seorang penyampai pesan atau bisa jadi prajurit-prajurit. John D. Currid, Strong and Courageous: Joshua Simply Explained (England: EP Books, 2011), 36.

${ }^{25}$ WTM Morphology, Word Analysis, In Bible Works Version 7, s.v. "כָ".

${ }^{26}$ John melihat ini sebagai kebijaksanaan dari Rahab. Ia mengakui akan kebijaksanaan Rahab ketika menjawab pertanyaan para utusan raja. Tidak panik dan bingung menindak lanjuti perintah raja, namun ia dengan tenang menjawab dan mengakui keberadaan dua pengintai di rumahnya. John D. Currid, Strong and Courageous: Joshua Simply Explained (England: EP Books, 2011), 36.

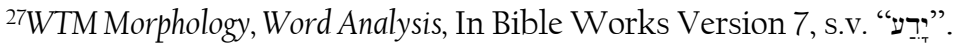

${ }^{28}$ Ibid., s.v. "x".

${ }^{29}$ Ibid., s.v. "אין". 
asal kedua orang yang tinggal di rumahnya. Namun, Rahab sebenarnya tahu akan kedua pengintai itu.

Di dalam kesaksian Rahab kepada kedua pengintai di atas sotoh rumah (ay. 9-11), dapat diketahui bahwa Rahab sebenarnya mengetahui asal dari kedua pengintai. Di dalam ayat 9, mengakui bahwa Tuhan telah menyerahkan bangsa Kanaan kepada "kamu". Di dalam ayat 10, Rahab menambahkan bahwa ia sudah mendengar akan perbuatan ajaib Tuhan ketika "kamu" keluar dari tanah Mesir. "Kamu" dalam konteks ayat 9-10 mengacu kepada orang-orang Israel atau bangsa Israel. ${ }^{30}$ Sedangkan, Tuhan yang Rahab maksudkan adalah Tuhan Allah bangsa Israel. Jadi, mengacu kepada percakapan yang Rahab mulai di atas sotoh rumah, sebenarnya Rahab mengenal atau tahu asal kedua pengintai dari kebangsaan Israel.

Lalu, kebohongan Rahab yang kedua adalah dengan berkata bahwa kedua pengintai itu telah pergi keluar dari pintu gerbang kota (ay. 5). Rahab berkata kedua pengintai itu telah pergi ketika pintu gerbang hendak ditutup menjelang malam. Kata yang dipergunakan adalah atau yatsa (bentuk qal perfek orang ke-3 jamak) ${ }^{31}$ yang dalam konteks ini menunjukkan bahwa kejadian keluarnya kedua pengintai itu telah berlangsung. Jadi Rahab mengemukakan kepada utusan raja Yerikho bahwa memang sebelumnya kedua pengintai ada namun mereka telah pergi keluar dari kota. Setelah itu Rahab berkata bahwa ia juga tidak mengetahui ke mana "orang-orang itu" atau dalam hal ini kedua pengintai, padahal sebenarnya Rahab tahu persis keberadaan kedua pengintai.

Rahab sendiri yang membawa kedua pengintai ke sotoh rumah (ay. 4a). Rahab juga yang menyembunyikan mereka di bawah tumpukan batang rami (ay. 6). Ini menjadi bukti yang jelas yang menunjukkan bahwa Rahab tahu keberadaan kedua pengintai. Namun, Rahab memberikan keterangan palsu dengan berkata kedua pengintai itu telah pergi keluar gerbang dan berkata tidak tahu kemana mereka pergi (ay. 5). Bahkan setelah itu Rahab menyuruh para utusan raja untuk pergi mengejar kedua pengintai yang katanya telah kabur (5b) dan demikian orang-orang yang mendengarkan kesaksian Rahab pergi ke arah sungai Yordan untuk mengejar kedua pengintai (ay. 7). Jadi, Rahab memberikan keterangan tidak benar ketika ditemui oleh para utusan raja dan ini dikarenakan kepercayaannya. Dengan demikian terbukti bahwa Rahab telah berbohong kepada para utusan raja demi melindungi kedua pengintai.

Kebohongan Rahab menjadi kasus tersendiri yang banyak menimbulkan masalah. Karena Rahab memperoleh keselamatan,

${ }^{30}$ D. C. Mulder, Tafsiran Alkitab: Kitab Yosua (Jakarta: BPK Gunung Mulia, 2015), 22.

${ }^{31}$ WTM Morphology, Word Analysis, In Bible Works Version 7, s.v. " “wָָּ". 
kebohongan Rahab juga dipandang benar dan akhirnya secara umum kebohongan yang didasarkan untuk kebaikan ditoleransi. Dalam buku The Bible Knowledge Commentary mencantumkan salah satu pandangan mengenai kebohongan Rahab. Tertulis bahwa kebohongan Rahab merupakan masalah budaya. Rahab yang lahir dan tumbuh di antara orang-orang Kanaan kemungkinan kebohongan menjadi suatu hal yang wajar. Menurut pandangan ini, Rahab tidak memandang adanya kesalahan dari tindakannya. ${ }^{32}$ Demikian juga yang dicantumkan di dalam Alkitab Penuntun Hidup Berkelimpahan. Dituliskan bahwa saat itu Rahab bukanlah anggota masyarakat perjanjian dan tidak terikat dengan hukum-hukum moral perjanjian. ${ }^{33}$ Jadi, berdasarkan pandangan ini, tindakan Rahab yang berbohong dapat ditoleransi karena latar belakang budaya atau kebangsaan Rahab dan statusnya sebagai orang yang tinggal di luar hukum perjanjian sehingga belum mengenal hukum Allah.

Namun, berbeda dengan pendapat Bakker. Dalam bukunya Sejarah Kerajaan Allah 1, Bakker mengungkapkan bahwa tindakan Rahab yang berbohong harus dicela. Perlindungan yang diberikan Rahab kepada para pengintai memang baik, tetapi cara melakukannya, yaitu dengan berbohong tidak patut ditiru. ${ }^{34}$ Jadi, bagi Bakker, kebohongan Rahab tidak dapat ditoleransi dan ditiru. Demikian halnya yang dikemukakan Theodore. Dalam tulisannya, Theodore juga menyatakan bahwa kebohongan Rahab tidak dapat dimaafkan. ${ }^{35}$ Menurut pandangan kedua, perbuatan tidak jujur Rahab patut dicela, meskipun untuk tujuan melindungi kedua pengintai.

Beralih ke pandangan yang berikutnya. D. C. Mulder memiliki pandangan yang sedikit berbeda dari kedua pandangan di atas. Bagi Mulder, kedua aktivitas yang Rahab lakukan tidak dapat dipisahkan. Mulder mengungkapkan bahwa agaknya tidak ada alasan untuk memisahkan kedua perbuatan Rahab (antara menyembunyikan kedua pengintai dan berbohong) dengan memuji tindakan yang pertama dan menyalahkan tindakan yang kedua. Rahab melindungi kedua pengintai dengan perbuatan dan kata (tipu muslihatnya) dan dengan jalan itu

${ }^{32}$ John F. Walvoord dan Roy B. Zuck, The Bible Knowledge Commentary (United States of America: Victor Books, 1985), 331.

${ }^{33}$ Donald C. Stamps, ed., Alkitab Penuntun Hidup Berkelimpahan (Malang: Gandum Mas, 2010), 337.

${ }^{34}$ F. L. Bakker, Sejarah Kerajaan Allah 1: Perjanjian Lama (Jakarta: BPK Gunung Mulia, 2004), 393.

${ }^{35}$ Theodore H. Epp, Joshua - Victorious by Faith (Nebraska: Back To The Bible Broadcast, 1968), 93. 
Rahab bertindak setia terhadap umat Tuhan dan terhadap Tuhan sendiri, ujar Mulder. ${ }^{36}$

Seperti yang sudah dijelaskan, kebohongan Rahab tidak secara langsung dicatatkan oleh penulis kitab Yosua, namun dari tindakan Rahab yang mengecoh utusan raja Yerikho, diketahui bahwa Rahab berbohong. Menilai kebohongan Rahab, jika mengacu kepada pandangan pertama, cukup masuk akal untuk menolerasi tindakan Rahab. Kondisi bangsa Kanaan yang hidup dalam penyembahan berhala dan perzinaan yang hebat, kemungkinan besar ketidakjujuran juga tumbuh di bangsa ini. Tidak adanya hukum Allah membuat mereka liar. Namun, hal ini kurang bisa dipertahankan karena kurangnya atau bahkan tidak ada literatur yang membahas mengenai kebudayaan bangsa Kanaan ini. Kebanyakan literatur hanya menyatakan akan kondisi bangsa Kanaan yang hidup dalam perzinaan, penyembahan berhala dan pembunuhan anak-anak, ${ }^{37}$ tidak ada yang dengan jelas menyatakan bahwa ada kebiasaan berbohong juga di tanah Kanaan.

Selain itu, jika mengacu kepada pandangan kedua, tindakan Rahab tidak dapat ditoleransi. Kebohongan tetaplah kebohongan dan hal tersebut adalah dosa. Pandangan ini menunjukkan ketegasan dan keseriusan bahwa apa yang Rahab lakukan sebenarnya tidak sepenuhnya benar dan baik. Di satu sisi Rahab sudah melindungi pengintai dengan menyembunyikan mereka, namun di sisi lain ia berbohong untuk melindungi mereka. Pandangan ini baik karena menegaskan bahwa kebohongan adalah tetap kebohongan dan itu adalah perbuatan dosa. Kebohongan Rahab adalah salah dan tidak dapat dimaklumi. Namun, penulis lebih sependapat dengan apa yang Mulder sampaikan.

Penulis setuju bahwa kebohongan adalah tindakan yang salah dan tidak patut dilakukan. Namun, tidak dapat dipungkiri bahwa melalui kebohongan juga Rahab melindungi kedua pengintai. Seperti yang Mulder ungkapkan bahwa tidak ada alasan untuk memisahkan kedua perbuatan itu dan memuji yang pertama sambil menyalahkan yang kedua. ${ }^{38}$ Bagi penulis, kebaikan dan kepercayaan Rahab terwujud ketika ia menyembunyikan kedua pengintai, tetapi melalui kebohongannya juga terwujud kebaikan dan kepercayaan Rahab. Kebohongan Rahab juga patut dipandang sebagai "perbuatan baik" dalam kaitannya dengan rancangan penyelamatan Allah terhadap kedua pengintai. Hal ini dikarenakan bukan hanya melalui tindakan menyembunyikan, tetapi dengan berbohong,

${ }^{36}$ D. C. Mulder, Tafsiran Alkitab: Kitab Yosua (Jakarta: BPK Gunung Mulia, 2015), 2122.

${ }^{37}$ W. S. Lasor, D. A. Hubbard, dan F. W. Bush, Pengantar Perjanjian Lama 1: Taurat dan Sejarah (Jakarta: BPK Gunung Mulia, 1993), 292.

${ }^{38}$ D. C. Mulder, Tafsiran Alkitab: Kitab Yosua (Jakarta: BPK Gunung Mulia, 2015), 22. 
Rahab juga menyelamatkan kedua pengintai dari ancaman utusan-utusan raja Yerikho.

Sebagai kesimpulan di bagian awal, seperti ungkapan Mulder, melalui kedua tindakannya ini (menyembunyikan pengintai dan berbohong) Rahab sedang menunjukkan kesetiaannya kepada kedua pengintai dan terlebih kepada Allah. ${ }^{39}$ Melalui dua tindakan Rahab di awal kisahnya, menunjukkan akan kepercayaannya kepada Allah. Ketika Rahab memutuskan untuk melindungi para pengintai pasti akan ada konsekuensi. Nyawanya dipertaruhkan dalam hal ini. Jika saja tindakannya diketahui oleh para utusan, maka pasti Rahab dihukum, bahkan bisa jadi ia dibunuh. ${ }^{40}$ Namun Rahab yakin bahwa keteguhan hatinya memihak kepada Allah akan berbuah baik. Rahab pasti sungguh percaya bahwa melalui perbuatannya, Allah melihat dan akan meluputkannya dari kematian dan hal ini berkaitan dengan pengakuan serta permintaan Rahab di ayat 9-13.

\section{Pengakuan Rahab (ayat 9-11)}

Ada beberapa hal yang Rahab akui di dalam ayat 9-11. Pengakuan pertama adalah Rahab tahu jikalau Tuhan telah memberikan negeri Kanaan kepada bangsa Israel (ay. 9). Ketika Rahab mengucapkan kata "Tuhan", ia menggunakan nama Allah bangsa Israel yaitu "Yehwah/Yahweh" (יהוֹ):. ${ }^{41}$ Ketika Rahab menyebutkan kata "Tuhan", ia tidak menggunakan nama yang sama dengan allah-allah/ilah-ilah bangsanya. ${ }^{42}$ Sebagai seorang perempuan Kanaan yang hidup dalam penyembahan berhala, pastinya ini merupakan sebuah hal yang luar biasa. Rahab tahu akan Allah bangsa Israel dan menyebutkan nama-Nya. John mengungkapkan, kata Ibrani "Yahweh" memberikan sebuah ide akan adanya pengenalan yang dalam dari si pengguna kata itu. Mengacu kepada Rahab, John percaya bahwa Rahab punya keyakinan yang kuat bahwa apa yang baru saja ia sampaikan benar adanya. ${ }^{43}$

Beranjak dari tokoh Rahab, kata "tahu" (dalam konteks ayat 9),

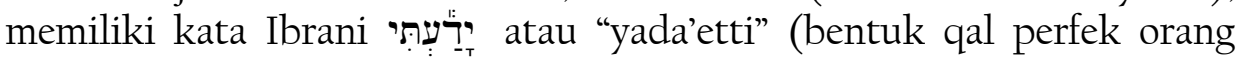

${ }^{39}$ D. C. Mulder, Tafsiran Alkitab: Kitab Yosua (Jakarta: BPK Gunung Mulia, 2015), 22.

${ }^{40}$ F. L. Bakker, Sejarah Kerajaan Allah 1: Perjanjian Lama (Jakarta: BPK Gunung Mulia, 2004), 393.

${ }^{41}$ Pada dasarnya nama "Tuhan" dalam kata Ibrani tidak menggunakan huruf vokal, yaitu YHWH atau יהוה.

${ }^{42}$ Kata YHWH yang dipergunakan Rahab adalah nama Ibrani yang mengacu kepada perjanjian. Kata YHWH, sama dengan kata yang Allah nyatakan kepada Musa ketika peristiwa semak terbakar (Keluaran 2). John D. Currid, Strong and Courageous: Joshua Simply Explained (England: EP Books, 2011), 37.

${ }^{43}$ John D. Currid, Strong and Courageous: Joshua Simply Explained (England: EP Books, 2011), 37. 
pertama tunggal dari kata dasar "yada" atau ידיריע) yang artinya "saya sudah tahu", "saya sudah menyadari" atau "saya sudah mengerti". ${ }^{44}$ Kata "saya" menunjuk kepada pribadi Rahab. Jadi, sesungguhnya Rahab sudah mengetahui atau menyadari bahwa Allah (YHWH) telah memberikan negeri ini kepada "kamu", yang dalam hal ini adalah seluruh orang-orang Israel.

Kata "memberikan" dalam kata Ibrani dan konteks ayat ini adalah נָת atau "natan" (bentuk qal perfek orang pertama tunggal dari kata dasar "natan") yang berarti "memberikan", "menyerahkan sepenuhnya" atau "menghadiahkan". Berdasarkan konteks ayat 9, Allah sesungguhnya sudah memberikan atau menyerahkan "negeri ini" 45 kepada bangsa Israel. Jadi, dari bagian ini Rahab mengakui bahwa dirinya mengetahui dan telah sadar bahwa negeri Kanaan telah berada di tangan bangsa Israel karena Allah telah menyerahkan mereka ke dalam kuasa bangsa Israel.

Kemudian, pengakuan kedua Rahab adalah mengakui bahwa bangsa Kanaan saat itu sedang mengalami ketakutan besar (ay. 9, lla). Di ayat 9 Rahab melanjutkan pengakuannya dengan berkata: bahwa kengerian terhadap kamu telah menghinggapi kami dan segala penduduk negeri ini gemetar menghadapi kamu (ay. 9b). Rahab berkata ada "kengerian yang menghinggapi kami." Kata "kengerian" berasal dari kata "eyma" (אימָה) yang artinya teror, kengerian, atau ketakutan. ${ }^{46}$ Kata "menghinggapi" berasal dari kata "nafela" atau נָּרלדה (bentuk qal perfek orang ke-3 tunggal feminim dengan

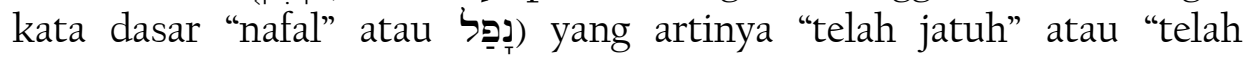
menimpa". ${ }^{47}$ Berdasarkan arti kata asli, Rahab berkata bahwa kengerian atau ketakutan telah jatuh atau menimpa - dalam hal ini - orang-orang Kanaan. ${ }^{48}$ Jadi, kengerian ini bukan hanya menimpa kota Yerikho, namun seluruh orang-orang di tanah Kanaan. Selain itu, Rahab menambahkan bahwa penduduk negeri Kanaan merasa "gemetar menghadapi" orangorang Israel.

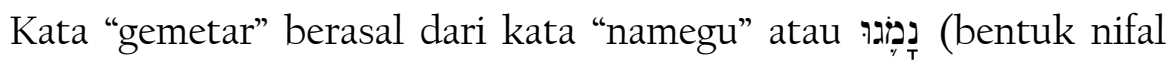
perfek orang ke-3 jamak) yang artinya "telah menjadi ragu-ragu, mencair, pudar, atau lama-lama memudar". ${ }^{49}$ Jadi, Rahab juga mengakui bahwa

${ }^{44}$ WTM Morphology, Word Analysis, In Bible Works Version 7), s.v. “"ירָעי"

${ }^{45}$ Kata "negeri" (erets $\mathbf{x}$ ) tidak hanya mengacu kepada kota Yerikho saja.

Namun, ketika Rahab berkata negeri ini maksudnya adalah seluruh tanah Kanaan. John F. Walvoord dan Roy B. Zuck, The Bible Knowledge Commentary (United States of America: Victor Books, 1985), 331.

${ }^{46}$ WTM Morphology, Word Analysis, In Bible Works Version 7, s.v. "אימָה".

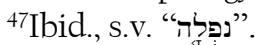

${ }^{48}$ John D. Currid, Strong and Courageous: Joshua Simply Explained (England: EP Books, 2011), 37 .

${ }^{49}$ WTM Morphology, Word Analysis, In Bible Works Version 7, s.v. "“דָיָּ". 
seluruh negeri telah gemetar, dalam artian merasa ragu-ragu bahkan menjadi pudar karena adanya rasa ketakutan terhadap bangsa Israel.

Pengakuan yang ketiga adalah pengakuan Rahab bahwa ia beserta seluruh orang Kanaan telah mendengar akan perbuatan Allah yang dahsyat dan tindakan Allah-lah yang sesungguhnya membuat semangat mereka jatuh. Di dalam ayat 10, ada 2 peristiwa yang membuat semangat orang-orang Kanaan jatuh. Peristiwa pertama, adalah peristiwa Allah mengeringkan Laut Teberau ketika bangsa Israel hendak melarikan diri dari kejaran tentara Mesir (Kel. 14:21). Berkat tangan kuasa Allah dan melalui hamba-Nya Musa, Allah menunjukkan kuasa-Nya dengan mengeringkan Laut Teberau sehingga bangsa Israel bisa melanjutkan perjalanan mereka dan terluput dari kejaran tentara Mesir. Peristiwa kedua adalah peristiwa bangsa Israel mengalahkan kedua raja bangsa Amori, yaitu Sihon dan Og (Bil. 21:21-35). Rahab mengakui bahwa mereka gemetar mendengar akan peristiwa yang terjadi oleh karena perbuatan Allah bagi bangsa Israel.

Di ayat 11 Rahab kembali menunjukkan bahwa orang-orang Kanaan sedang dalam ketakutan dengan berkata bahwa mereka saat itu merasa "tawar hati" dan "jatuh semangat" menghadapi orang Israel (ay. lla). Kata "tawar hati" berasal dari 2 suku kata yaitu "wayyimmas" dan "lebabenu"

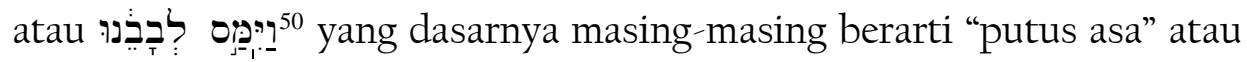
"merasa lemah" (wayyimmas) dan "hati" (lebabenu). Jadi, secara sederhana "tawar hati" adalah kondisi merasa putus asa atau lemah hati. Lalu, kata "jatuh semangat" sendiri memiliki makna bahwa semangat atau jiwa tidak dapat berdiri atau tidak dapat bangkit tetap. ${ }^{51}$ Jadi, mengacu kepada pengakuan Rahab, orang-orang Kanaan saat itu mengalami lemah hati dan jiwa atau semangat mereka tidak dapat berdiri tetap ketika menghadapi bangsa Israel. Rahab sebenarnya ingin menyatakan kepada kedua pengintai bahwa ketika diperhadapkan dengan bangsa Israel, orang-orang Kanaan merasa ketakutan, merasa lemah dan semangat mereka juga jatuh. Bangsa Kanaan telah benar-benar kehilangan semangat mereka menghadapi bangsa Israel. 52

Ketakutan ini timbul bukan hanya karena bangsa Israel, namun kuasa yang besar yang melindungi bangsa Israel, yaitu kuasa dari Tuhan Allah.

50"Wayyimmas" berbentuk nifal imperfek orang ke-3 tunggal dari kata dasar atau "Masas". Sedangkan "lebabnu" merupakan kata benda berbentuk maskulin jamak

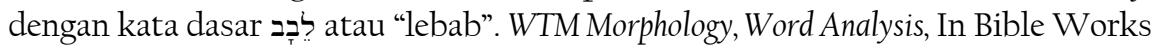

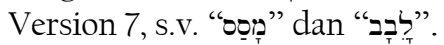

${ }^{51}$ Frasa "jatuh semangat" cukup panjang dalam Bahasa Ibrani yaitu "welo-qama od

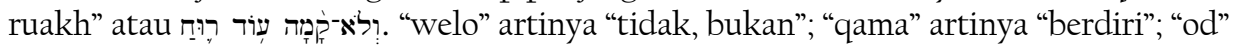
artinya "tetap"; dan "ruakh" artinya "jiwa, roh atau nafas". Ibid., Joshua 2:11.

${ }^{52}$ John F. Walvoord dan Roy B. Zuck, The Bible Knowledge Commentary (United States of America: Victor Books, 1985), 331. 
Mereka gemetar dengan kuasa Tuhan yang mampu membelah Laut Teberau dan membawa bangsa Israel luput dari kejaran bangsa Mesir. Bangsa Kanaan juga takut karena kuasa Allah yang telah memampukan mereka untuk menang menghadapi raja orang Amori, yaitu Sihon dan Og. Sesungguhnya, faktor utama yang menimbulkan ketakutan besar dari bangsa Kanaan adalah betapa dahsyat dan besarnya kuasa Tuhan Allah Israel yang melindungi dan menaungi mereka. Oleh sebab itu, hal ini diakui oleh Rahab dalam ayat 11 bagian akhir.

Pengakuan terakhir Rahab adalah ia mengakui bahwa Tuhan Allah bangsa Israel adalah Tuhan Allah di langit di atas dan di bumi di bawah. Setelah melihat akan perbuatan ajaib Allah dan merasakan gentar di hadapan kuasa Allah, Rahab sadar bahwa Tuhan Allah Israel adalah Tuhan yang berkuasa di langit dan di bumi.

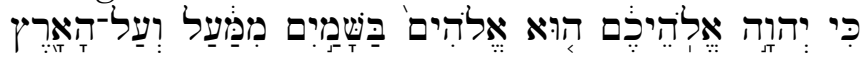

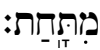

Ki Yehwah elohekhem hu Elohim basysyamayim mimma'al weal-ha'arets mittakhat.

Partikel "ki" ketika dipergunakan memiliki arti "sungguh" atau "benar". 53 "Yehwah/Adonay elohekhem" memiliki arti Tuhan, Allahmu dan dalam hal ini yang Rahab maksud adalah Tuhan Allah bangsa Israel. Kata "hu" menunjuk kepada kata ganti, seperti "dia" atau "mereka". ${ }^{54}$ "Elohim basysyamayim mimma'al" merupakan frasa dengan arti "Allah di langit atau surga dari atas". Sedangkan "weal-ha'arets mittakhat" berarti "dan di atas bumi dari bawah". ${ }^{55}$ Jadi, perkataan Rahab berarti: "Sungguh Tuhan Allahmu Dia Allah di langit/surga dari atas dan di atas bumi dari bawah." Ini merupakan pengakuan yang sangat luar biasa dari seorang perempuan sundal bangsa non-Israel. Rahab mengakui bahwa memang benar Allah bangsa Israel adalah Allah atas seluruh bumi. Allah bangsa Israel adalah Allah pencipta alam semesta dan yang mengurusnya. ${ }^{56}$ Tuhan Allah Israel adalah Allah yang berkuasa di surga atau langit dan juga Allah yang berkuasa di bumi. Seperti yang Mulder ungkapkan, perkataan Rahab menunjukkan pengakuaannya akan keesaan Allah. Rahab menginsyafi bahwa Tuhan itu Allah yang sama sekali unggul. ${ }^{57}$

Kepercayaan Rahab terbukti dalam pengakuannya akan Allah bangsa Israel. ${ }^{58}$ Rahab dengan jelas menyatakan bahwa Allah bangsa Israel merupakan "Allah di langit di atas dan di bumi di bawah". Respons Rahab

\footnotetext{
${ }^{53}$ WTM Morphology, Word Analysis, In Bible Works Version 7, s.v. "פ”".

${ }^{54}$ Ibid., s.v. "הוּוּ"

${ }^{55}$ Ibid., Joshua 2:11.

${ }^{56}$ Abraham Park, Pelita Perjanjian Yang Tak Terpadamkan (Jakarta: Grasindo, 2012),

${ }^{57}$ D. C. Mulder, Tafsiran Alkitab: Kitab Yosua (Jakarta: BPK Gunung Mulia, 2015) 23.

${ }^{58}$ Frank E. Gaebelein, The Expositor's Bible Commentary (Michigan: Zondervan Publishing House, 1992), 262.
} 134. 
berbeda dari orang-orang Kanaan lain. Orang Kanaan lain menanggapi dengan rasa takut, gemetar dan lemah di hadapan kuasa Allah dan cukup sampai demikian. Namun, di sisi lain rasa takut itu, Rahab merespons kuasa Tuhan dengan pengakuan bahwa benar, Allah bangsa Israel adalah Allah yang punya kuasa di langit di atas dan di bumi di bawah. ${ }^{59}$ Melalui pengakuannya, melalui kata-katanya, Rahab sedang memproklamasikan bahwa Allah bangsa Israel (Yahweh) merupakan Allah di atas segalanya. ${ }^{60}$

\section{Permintaan Rahab (ayat 12-13)}

Di ayat 12, Rahab memulai dengan berkata "maka sekarang ..." Frasa "maka sekarang" mengacu tindakan yang akan dilakukan setelah setiap perkataan atau pengakuan Rahab di ayat 9-1l. Setelah Rahab mengungkapkan situasi dari negeri Kanaan, Rahab ternyata saat itu hendak mengajukan permintaan. Rahab mengawali permintaannya dengan meminta kedua pengintai untuk bersumpah demi Tuhan. Rahab berharap supaya kedua pengintai bersumpah untuk berlaku ramah kepada keluarganya dan memberikan tanda yang dapat dipercaya.

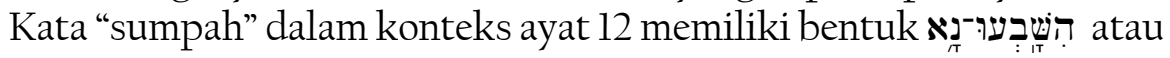
"hisysyabe'u-na” (kata dasar "syaba" atau שָׁבָע: bentuk kata kerja nifal imperatif maskulin jamak). "Sumpah" dalam hal ini memiliki pengertian membuat sebuah pernyataan atau janji, dengan bersumpah atau mengucapkan janji yang melibatkan Allah serta menjanjikan sesuatu hal yang bernilai. ${ }^{61}$ Jadi, ketika Rahab meminta kedua pengintai untuk bersumpah sesungguhnya ia sedang meminta mereka untuk membuat sebuah pernyataan atau janji yang melibatkan Allah di dalamnya dan dalam hal ini Rahab ingin supaya kedua pengintai berjanji meluputkan keluarganya dari kematian. Hal ini Rahab harapkan dikarenakan ia telah "berlaku ramah" terhadap kedua pengintai.

Dalam kondisi penuh ancaman, kedua pengintai memperoleh perlindungan dari Rahab. Mereka disembunyikan keberadaannya dari kedatangan para utusan raja Yerikho. Itu menjadi bentuk perlakuan ramah Rahab kepada kedua pengintai. Oleh sebab itu, Rahab juga menghendaki supaya kedua pengintai berlaku ramah kepada keluarganya. Rahab ingin supaya kedua pengintai membiarkan hidup ayah, ibu, saudara-saudara laki-laki dan perempuan, serta semua orang mereka. Rahab menghendaki supaya kedua pengintai menyelamatkan nyawa mereka semua dari pembantaian yang akan segera terjadi. Lebih daripada itu, sesungguhnya kata "ramah" memiliki makna yang cukup dalam.

${ }^{59}$ John F. Walvoord dan Roy B. Zuck, ed., The Bible Knowledge Commentary (United States of America: Victor Books, 1985), 331.

${ }^{60}$ John D. Currid, Strong and Courageous: Joshua Simply Explained (England: EP Books, 2011), 38 .

${ }^{61}$ WTM Morphology, Word Analysis, In Bible Works Version 7, s.v. “שֵָׁ" 
Kata yang Rahab pakai untuk menunjukkan kebaikan dan keramahannya kepada kedua pengintai dalam Bahasa Ibrani adalah חס atau "khesed". Kata "khesed" memiliki arti "kewajiban kepada sebuah komunitas", "kesetiaan", "kebaikan", dan "dukungan". ${ }^{2}$ The Bible Knowledge Commentary mencatatkan bahwa "khesed" beberapa kali dipergunakan dalam perjanjian Allah untuk umat-Nya. Selain itu, terkadang kata ini juga dipergunakan dalam kaitannya dengan hubungan antara sesama manusia dan dalam hal ini kaitannya dengan Rahab dan kedua pengintai. Lebih lanjut dituliskan demikian: Rahab's request was that the spies make a hesed agreement with her and her father's family, just as she made a hesed agreement with them by sparing their lives. Yang dinyatakan dari buku The Bible Knowledge Commentary adalah sebenarnya saat itu permintaan Rahab adalah supaya kedua pengintai membuat sebuah "perjanjian khesed" dengan dirinya dan juga dengan keluarga Rahab seperti perjanjian yang dilakukan Rahab dengan kedua pengintai melalui cara menyelamatkan nyawa mereka. ${ }^{63}$ Berdasarkan pernyataan tersebut, Rahab ternyata hendak membuat sebuah perjanjian yang didasarkan pada kesetiaan atau kebaikan yang telah ia lakukan. Melalui tindakannya menyelamatkan kedua pengintai, Rahab menunjukkan kesetiaannya dan keramahannya kepada kedua pengintai namun itu juga menjadi dasar dari perjanjian yang hendak ia bangun dengan kedua pengintai. Selain itu, tidak hanya dengan dirinya sendiri, Rahab juga ingin kedua pengintai melibatkan keluarga Rahab dalam perjanjian yang didasarkan kesetiaan itu. Dengan berlaku ramah terhadap kedua pengintai, Rahab berharap dirinya beserta keluarganya (ayah, ibu, saudara laki-laki dan perempuan beserta orang-orangnya) diselamatkan (ay. 13). Rahab menunjukkan kepercayaannya tidak hanya dengan melindungi kedua pengintai, namun kepercayaan juga diperlihatkan melalui bebannya terhadap keselamatan keluarganya. ${ }^{64}$ Rahab sadar bahwa bukan hanya dirinya sendiri yang perlu diselamatkan, namun keluarganya juga punya kebutuhan yang sama bahwa mereka ingin diluputkan dari kematian.

Rahab mengawali permintaannya dengan memohon kepada kedua pengintai untuk bersumpah, sumpah demi nama Tuhan. Kembali nama yang Rahab pakai untuk menyebut nama Tuhan adalah יהוז: atau "Yehwah", Allah bangsa Israel. Rahab sadar akan kuasa Allah bangsa Israel dan kekuasaannya yang meliputi seluruh jagat raya. Kekuatan yang telah membawa bangsa Israel sampai hampir memasuki tanah Kanaan dan yang membawa ketakutan bagi seluruh negeri Kanaan, Rahab tahu akan kuasa

\footnotetext{
${ }^{62}$ WTM Morphology, Word Analysis, In Bible Works Version 7, s.v. "“חסק".

${ }^{63}$ John F. Walvoord dan Roy B. Zuck, ed., The Bible Knowledge Commentary (United

States of America: Victor Books, 1985), 332.

${ }^{64}$ Ibid.
} 
tersebut (ay. 9). Rahab meminta kedua pengintai untuk bersumpah demi Allah mereka karena ia tahu dan percaya akan kuasa nama Tuhan Allah Israel. Oleh sebab itu, Rahab ingat dan meminta kedua pengintai untuk bersumpah demi nama Tuhan sebelum berjanji. Demikian juga, ketika Rahab memintai kedua pengintai untuk menyelamatkan dirinya beserta keluarganya, ia menunjukkan kepercayaannya kepada Tuhan bahwa di dalam Tuhan Allah Israel ada keselamatan bagi keluarganya. ${ }^{65}$ Rahab tidak hanya memikirkan keselamatan diri sendiri, namun keluarganya juga menjadi perhatiannya sekaligus. ${ }^{66} \mathrm{Jadi}$, melalui permintaannya kepada kedua pengintai: untuk bersumpah demi Tuhan dan menyelamatkan Rahab beserta kaum keluarganya, Rahab sedang menunjukkan kepercayaannya pada Tuhan dan umat-Nya.

\section{Rahab Menolong Kedua Pengintai Kabur (15-16)}

Setelah dialog yang dilakukan oleh Rahab dan kedua pengintai, akhirnya Rahab menolong kedua pengintai untuk kabur dari kota Yerikho. Rahab menolong mereka pergi dari Yerikho dengan cara menurunkan mereka dengan menggunakan tali melalui jendela (ay. 15a). Hal ini dipandang mudah karena informasi mengatakan posisi rumah Rahab yang berada di tembok kota Yerikho (ay. 15b). Jadi, kemungkinan besar ketika Rahab menurunkan tali melalui jendela mereka sudah berada di luar dari kota Yerikho. ${ }^{67}$ Selain menolong kedua pengintai untuk kabur, Rahab juga memberikan sedikit arahan kepada kedua pengintai.

Ayat 16 mencatatkan instruksi yang diberikan Rahab kepada kedua pengintai. Rahab berkata: Pergilah ke pegunungan, supaya pengejar-pengejar itu jangan menemui kamu, dan bersembunyilah di sana tiga hari lamanya, sampai pengejar-pengejar itu pulang; kemudian bolehlah kamu melanjutkan perjalananmu. Kata "pergilah" berasal dari kata לִ לִ atau "lekhu" yang merupakan sebuah bentuk perintah atau dorongan untuk pergi atau berjalan (kata dasar הָרָ atau halakh: bentuk imperatif maskulin jamak). ${ }^{68} \mathrm{Jadi}$, yang disampaikan oleh Rahab adalah sebuah suruhan atau dorongan kepada kedua pengintai untuk pergi. Rahab mendorong kedua pengintai untuk pergi menuju ke pegunungan dan bersembunyi di sana selama tiga hari agar para pengejarpengejar tidak menemukan mereka.

\footnotetext{
${ }^{65}$ R. E. Harlow, Winning e Losing: Studies in Joshua, Judges, Ruth (Canada: Everyday Publication Inc., 1984), 13.

${ }^{66}$ John F. Walvoord dan Roy B. Zuck, ed., The Bible Knowledge Commentary (United States of America: Victor Books, 1985), 331.

${ }^{67}$ John D. Currid, Strong and Courageous: Joshua Simply Explained (England: EP Books, 2011), 39.

${ }^{68}$ WTM Morphology, Word Analysis, In Bible Works Version 7, s.v. “הלה".
} 
Instruksi Rahab sebenarnya membawa kedua pengintai untuk pergi ke arah yang berlawanan dengan arah perkemahan bangsa Israel. ${ }^{69}$ Ketika Rahab meminta mereka untuk pergi ke pegunungan, para penjaga sedang mengarah ke sungai Yordan (ay. 7) dan itu berada di sebelah timur dari Yerikho. Rahab mengarahkan kedua pengintai untuk pergi dan bersembunyi di pegunungan yang sebenarnya berada di daerah barat kota Yerikho. Rahab meminta mereka menunggu tiga hari supaya para pengejar pulang dan mereka bebas untuk pergi kembali ke perkemahan bangsa Israel di sebelah timur. ${ }^{70}$ Dari tindakan Rahab, dapat diketahui bahwa ia sungguh-sungguh menolong kedua pengintai.

Tindakan aktif Rahab yang hendak menolong kedua pengintai dengan menurunkan mereka dari jendela rumahnya merupakan sebuah bentuk pertolongannya dan kesetiaannya kepada para pengintai. Namun, tindakan Rahab tidak hanya menurunkan kedua pengintai. Rahab memberikan instruksi kepada kedua pengintai untuk menghindari kejaran dari para tentara Yerikho. Ia mendorong kedua pengintai untuk pergi ke pegunungan dan bersembunyi di sana. Rahab menolong kedua pengintai dengan sungguh-sungguh dan mengarahkan mereka kepada keselamatan dari para pengejar. Melalui tindakannya, Rahab sekali lagi menunjukkan akan keseriusannya untuk menolong kedua pengintai. Rahab rela mengambil resiko dengan mempertaruhkan nyawanya untuk menolong pengintai kabur. ${ }^{71}$ Melalui perbuatannya kepada para pengintai, Rahab menunjukkan kepercayaannya kepada Allah. ${ }^{72}$ Rahab yakin, dengan menjamin keselamatan kedua pengintai sampai ke tempat tujuan mereka, ia juga akan memperoleh keselamatan ketika bangsa Israel menjarah Yerikho. Tuhan Allah Israel, melalui umat-Nya, akan meluputkan dirinya dari kematian.

\section{Respons Rahab Terhadap Persyaratan Kedua Pengintai (ayat 17-21)}

Sebelum meninggalkan rumah Rahab, kedua pengintai menyampaikan persyaratan akan perjanjian yang Rahab dan para pengintai ikat serta konsekuensi jika melanggar perjanjian tersebut. Syarat pertama adalah Rahab harus mengikatkan tali kirmizi di jendela rumahnya. Tali kirmizi ${ }^{73}$ dipasang dengan tujuan supaya orang-orang

69"The Conquest of the Promised Land: Joshua - Ibiblio," 29, diakses 21 Juni 2017, www.ibiblio.org/ freebiblecommentary/pdf/EN/VOL04OT.pdf.

${ }^{70}$ John D. Currid, Strong and Courageous: Joshua Simply Explained (England: EP Books, 2011), 39-40.

${ }^{71}$ D. A. Carson, dkk., ed., New Bible Commentary (England: Inter-Varsity Press, 1995), 239.

${ }^{72}$ R. E. Harlow, Winning \& Losing: Studies in Joshua, Judges, Ruth (Canada: Everyday Publication Inc., 1984), 13.

${ }^{73}$ Beberapa pakar memandang kain kirmizi sebagai perlambang akan anak domba Paskah, yaitu darah anak domba yang dibubuhkan di tiang pintu rumah orang Israel 
Israel tidak menyerang atau membunuh orang-orang yang berada di rumah itu, dalam hal ini yaitu rumah Rahab. Oleh sebab itu, syarat pertama terkait juga dengan syarat kedua, yaitu Rahab harus mengumpulkan kaum keluarganya yang hendak diselamatkan.

Persyaratan kedua adalah Rahab harus membawa semua kaum keluarganya ke dalam rumahnya untuk mendapatkan perlindungan di sana (ay. 18b). Namun, ada awasan yang diberikan oleh kedua pengintai kepada Rahab. Para pengintai berkata bahwa jika orang yang keluar dari rumah dan mati, itu tidak menjadi tanggung jawab dari kedua pengintai. Jadi, kesalahan dari kematian orang tersebut tidak dijatuhkan kepada kedua pengintai. Sebaliknya, jika siapa pun yang berada di rumah dan ada seseorang yang menciderai mereka, maka kedua pengintailah yang menanggung kesalahan itu (ay. 19). Jadi, secara tidak langsung kedua pengintai melarang Rahab beserta keluarganya untuk keluar dari rumah ketika bangsa Israel datang menyerang kota Yerikho. Setelah itu, kedua pengintai kembali mengulangi konsekuensi jika Rahab melanggar perjanjian mereka dengan melaporkan keberadaan para pengintai, maka kedua pengintai bebas dari ikrar yang telah diucapkan (ay. 20). Dengan demikian, ada 3 kondisi yang Rahab perlu perhatikan: (1) Rahab harus mengikatkan kain kirmizi di jendela rumah, (2) Rahab harus mengumpulkan keluarganya di rumahnya dan melarang orang-orang untuk keluar jika orang Israel menyerang, serta (3) jangan mengabarkan perkara kedua pengintai kepada orang-orang Yerikho.

Kepercayaan Rahab dalam hal ini ditunjukkan melalui tindakan akhirnya yang tercatat di ayat 21 . Setelah kedua pengintai selesai berbicara, Rahab menanggapinya dengan berkata: Seperti yang telah kamu katakan, demikianlah akan terjadi. Rahab menyetujui setiap persyaratan dari kedua pengintai. Rahab tidak mengeluh atau mempertanyakan keputusan dari kedua pengintai, namun ia menerima setiap perkataan dan persyaratan kedua pengintai. Rahab menunjukkan kepercayaannya dengan menerima setiap konsekuensi dan persyaratan yang disampaikan oleh kedua pengintai. ${ }^{74}$ Pada akhirnya, diketahui bahwa Rahab melakukan apa yang diperintahkan oleh kedua pengintai. Setelah kedua pengintai pergi, Rahab langsung mengikatkan kain kirmizi di jendela di mana ia menurunkan kedua pengintai seperti yang diperintahkan kedua pengintai (Yos. 2:21 bnd. Yos. 2:18). Rahab menindaklanjuti apa yang

supaya melindungi mereka dari hukuman Allah (Kel. 12:21-23). Demikian halnya dengan kain kirmizi, yang melambangkan keamanan dan pembebasan bagi orang-orang di rumah tersebut. Selain itu, beberapa ahli juga menjadikan kain ini sebagai lambang darah Kristus yang membawa keselamatan. Donald C. Stamps, ed., Alkitab Penuntun Hidup Berkelimpahan (Malang: Gandum Mas, 2010), 338.

${ }^{74}$ Donald Guthrie, dkk., Tafsiran Alkitab Masa Kini l: Kejadian - Ester (Jakarta: Yayasan Komunikasi Bina Kasih, 2015), 355. 
disampaikan kedua pengintai dengan cepat. Kemungkinan, setelah itu Rahab juga buru-buru memberitahukan keluarganya apa yang diinstruksikan oleh kedua pengintai. ${ }^{75}$ Tindakan Rahab yang cepat memperlihatkan akan kepercayaan, keyakinan, keberanian dan ketaatan dari Rahab. ${ }^{76}$ Rahab yakin dengan menerima dan melakukan setiap persyaratan maka ia akan beroleh keselamatan.

\section{Implikasi Praktis Dari Kepercayaan Rahab Bagi Orang Kristen Masa Kini}

Kepercayaan Menuntut Pengakuan Dan Tindakan

Bukti yang sangat jelas dari kepercayaan Rahab adalah pengakuannya akan Allah. Rahab mengakui bahwa Allah bangsa Israel merupakan "Allah di langit di atas dan di bumi di bawah" (Yos. 2:11). Pengakuan Rahab menunjukkan bahwa ia percaya Allah umat Israel merupakan Allah di atas segalanya. ${ }^{77}$ Namun, mendahului pengakuannya, ada tindakan yang dilakukan Rahab untuk membuktikan kebergantungannya kepada Allah bangsa Israel, antara lain tindakan terebut adalah Rahab menolong kedua pengintai dengan menyembunyikan mereka dari para pengejar (ay. 4,6) serta berbohong kepada pengejar-pengejar untuk menutupi keberadaan para pengintai (ay. 4-6). Dari hal ini, perbuatan Rahab memiliki peran yang penting dalam keselamatan kedua pengintai, bahkan juga keselamatan dirinya sendiri. Tindakan baik Rahab menjadi satu faktor besar yang membuat dirinya diselamatkan dari kematian.

Dalam Yosua 6:25, Rahab terluput dari kematian ketika bangsa Israel datang untuk menjarah kota Yerikho karena pertolongan yang diberikannya kepada pengintai-pengintai untusan Yosua. Pastinya, kedua pengintai yang bertemu Rahab ingat jasa pertolongan Rahab. Tindakan Rahab yang berani menyembunyikan keberadaan mereka, menjadi sebuah langkah percaya yang besar.

Yakobus 2:25 juga mencantumkan nama Rahab serta menyatakan bahwa tindakan yang telah dilakukannya mendatangkan pembenaran bagi dirinya. Yakobus menuliskan bahwa Rahab telah dibenarkan sebab pertolongan yang diberikannya kepada para pengintai. Tindakan Rahab yang adalah wujud keyakinannya kepada Allah membawa keselamatan

75John F. Walvoord dan Roy B. Zuck, ed., The Bible Knowledge Commentary (United States of America: Victor Books, 1985), 332.

${ }^{76}$ John D. Currid, Strong and Courageous: Joshua Simply Explained (England: EP Books, 2011), 41 .

${ }^{77}$ John D. Currid, Strong and Courageous: Joshua Simply Explained (England: EP Books, 2011), 38 . 
bagi Rahab dan keluarganya. ${ }^{78}$ Jadi, tindakan Rahab membawa pembenaran bagi dirinya.

Selain itu, penulis surat Ibrani juga melihat tindakan Rahab sebagai bagian dari kepercayaan Rahab. Dituliskan bahwa iman Rahab terbukti melalui tindakannya yang menyambut dengan baik suruhan Yosua serta menolong mereka. Menurut penulis surat Ibrani, tindakan Rahab yang adalah wujud imannya, merupakan faktor yang membawa keluputan bagi Rahab dari kebinasaan (Ibr. 1l:31). Rahab berani mengambil tindakan yang dapat mengancam nyawanya. Edgar mengungkapkan bahwa keberanian Rahab untuk mengkhianati bangsanya merupakan wujud kepercayaannya kepada Allah. ${ }^{79}$ Rahab berani mempertaruhkan seluruh hari depannya kepada Allah yang sanggup membuat hal yang mustahil menjadi mungkin. ${ }^{80}$ Jadi, tindakan Rahab adalah wujud kepercayaannya kepada Allah di mana Rahab berani bertindak menentang bangsanya dan menunjukkan kesetiaannya kepada Allah bangsa Israel beserta umatNya. ${ }^{81}$ Dengan demikian, tindakan-tindakan yang dilakukan oleh Rahab merupakan hal yang sangat penting.

Melalui tindakannya, Rahab menunjukkan imannya. Melalui tindakan juga, Rahab memperoleh pembenaran, menunjukkan keberanian dan kesetiaannya serta diluputkan dari kebinasaan. Hal ini juga membuktikan bahwa pengakuan Rahab di hadapan kedua pengintai memang penting, namun tindakan Rahab juga lebih banyak menunjukkan akan kesetiaannya kepada para pengintai. Demikian juga, tidak hanya melalui pengakuan saja Rahab menunjukkan percayanya, namun tindakannya juga berperan menjadi bukti yang dapat dilihat dari kepercayaannya. ${ }^{82}$ Demikian juga pengakuan dan tindakan menjadi satu bagian yang penting dan tidak dapat dipisahkan. ${ }^{83}$

Rasul Paulus, dalam suratnya kepada jemaat di Roma menegaskan bahwa setiap orang yang mengaku Yesus Kristus adalah Tuhan akan beroleh selamat (Rom. 10:9) dan pengakuan tersebut diucapkan dengan mulut (ay. 10). Jadi, bagi Paulus pengakuan kepada Allah merupakan bagian yang tidak terlepas dari orang Kristen. Barangsiapa mengakui Yesus adalah Tuhan, orang tersebut sedang menunjukkan kepercayaannya dan akan memperoleh keselamatan. Ketika seseorang

\footnotetext{
${ }^{78}$ Rainer Scheunemann, Surat Yakobus (Jayapura: Sekolah Tinggi Teologi “I. S. Kijne," 2005), 89.

${ }^{79}$ Edgar Andrews, A Glorious High Throne (England: Evangelical Press, 2009), 394.

${ }^{80}$ Eka Darmaputera, Imamat Yang Sempurna (Jakarta: BPK Gunung Mulia, 2012), 159.

${ }^{81}$ David Gooding, An Unshakeable Kingdom (Michigan: William B. Eerdmans Publishing Company, n.d.), 236.

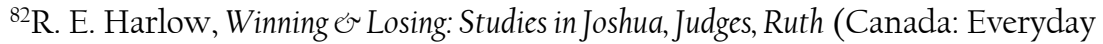
Publication Inc., 1984), 13.

${ }^{83}$ Eka Darmaputera, Iman Dalam Perbuatan (Jakarta: BPK Gunung Mulia, 2012), 71.
} 
mengakui Yesus adalah Tuhan, orang tersebut baru saja menunjukkan imannya dan artinya Roh Kudus ada di dalam dirinya (1 Kor. 12:3). Pengakuan bahwa orang tersebut percaya kepada Yesus Kristus merupakan bagian yang tidak terlepas dan penting untuk dilakukan oleh setiap orang percaya. Namun, tidak sedikit orang Kristen yang mengabaikan tindakan selanjutnya setelah mengaku.

Rasa cukup seringkali melingkupi orang-orang Kristen saat ini. Merasa cukup dengan mengaku dan berkata "saya percaya kepada Yesus Kristus sebagai Tuhan dan Juruselamat saya" menjadi titik akhir kebanyakan orang Kristen. Menaati dan melakukan kebenaran firman Tuhan tidak lagi menjadi prioritas utama. Hal ini dikarenakan rasa cukup karena sudah mengaku sebagai orang yang percaya kepada Yesus.

Yakobus dengan tegas menuliskan jikalau iman tanpa adanya perbuatan adalah mati (Yak. 2:26). Dikarenakan adanya pengertian yang salah akan iman yang menyelamatkan, maka Yakobus menekankan akan iman yang benar dalam suratnya. ${ }^{84}$ Yakobus dengan jelas menuliskan bahwa beriman berarti harus bertindak. ${ }^{85}$ Iman tanpa adanya tindakan perwujudan dari apa yang diimaninya merupakan kesia-siaan. Jadi, bagi Yakobus orang-orang yang mengaku percaya namun jika tidak dibarengi dengan adanya tindakan yang menunjukkan kepercayaannya, maka itu adalah iman kepercayaan yang mati (Yak. 2:14-17). Iman yang hidup adalah ketika pengakuan dibarengi dengan adanya perbuatan.

Hasan Sutanto berusaha menjelaskan maksud Yakobus sebagai berikut: "Yang dimaksudkan dalam Surat Yakobus adalah iman kepercayaan perlu dinyatakan dan dibuktikan melalui perbuatan." 86 Demikian halnya Rahab. Dalam kisahnya, Rahab memperlihatkan kepercayaannya selain dengan mengaku akan Allah bangsa Israel yang berada di atas segalanya tetapi juga bertindakan baik kepada umat Allah. Rahab menjadi teladan iman yang benar karena selain ia melakukan pengakuan formal bahwa Allah adalah Allah atas segala yang ada, ia juga melakukan tindakan baik (Yak. 2:25). ${ }^{87}$ Demikian halnya orang-orang Kristen harus memiliki iman yang hidup.

Iman hidup dengan mengaku bahwa Yesus adalah Tuhan dan melakukan perbuatan yang mewujudkan imannya. Iman dan perbuatan tidaklah dapat dipisahkan. Tidaklah cukup seseorang mengaku bahwa Yesus adalah Tuhan jikalau kehidupannya mengabaikan sikap hidup yang

\footnotetext{
${ }^{84}$ Donald C. Stamps, ed., Alkitab Penuntun Hidup Berkelimpahan (Malang: Gandum Mas, 2010), 2084.

${ }^{85}$ Howard Clark Kee, dkk., ed., Alkitab Edisi Studi (Jakarta: Lembaga Alkitab Indonesia, 2015), 2003.

${ }^{86}$ Hasan Sutanto, Surat Yakobus: Berita Perdamaian Yang Patut Didengar (Malang: Seminar Alkitab Asia Tenggara, 2006), 207.

${ }^{87}$ Ibid., 209.
} 
benar dan berkenan di hadapan Allah. Yang Allah kehendaki bukan hanya sekedar pengakuan kosong, namun juga perwujudan iman melalui tindakan.

Yakobus menegaskan bahwa jemaat Tuhan haruslah menjadi seorang pelaku kebenaran firman Tuhan, bukan hanya menjadi seorang pendengar (Yak. 1:22). Demikianlah orang-orang Kristen harus menjadi seorang pelaku kebenaran firman Tuhan. Tindakan hidupnya harus seturut dan sejalur dengan apa yang kebenaran Tuhan catatkan. Allah berkenan kepada kehidupan seturut dengan apa yang dikehendaki-Nya. Jadi, tindakan yang dimaksud dari bagian ini adalah tindakan yang seturut dengan firman Allah, dalam hal ini kebenaran yang tertulis di Alkitab.

Yesus mengajarkan kepada murid-murid untuk hidup dalam kasih: mengasihi Allah dan sesama (Mat. 22:37-39; Mrk. 12:28-34; Luk. 10:25-28). Tidak hanya mengasihi orang yang mengasihi diri kita, namun juga mengasihi musuh kita (Mat. 5:43-47; Luk 6:27-36). Oleh sebab itu, orang Kristen harus menyatakan kasih kepada orang-orang sekelilingnya. Yesus Kristus mengajarkan murid-murid untuk berdoa. Kita sebagai orang Kristen juga harus hidup di dalam doa (Mat. 6:5-13, 26:39). Demikianlah, jika kita mengaku hidup sebagai pengikut Kristus, percaya akan Yesus sebagai Tuhan, kita juga harus melakukan segala teladan Yesus dan melaksanakan apa yang Yesus ajarkan kepada murid-murid. Iman yang hidup dan berkenan di hadapan Allah merupakan iman yang didasarkan pada pengakuan akan Yesus sebagai Tuhan dan kehidupan yang menyatakan kebenaran dan kehendak Allah melalui tindakan nyata.

\section{Keselamatan Berlaku Bagi Semua Orang Yang Percaya}

Yosua 6 mencatatkan akan keselamatan Rahab dari serangan bangsa Israel (ay. 25). Rahab diluputkan dari kematian oleh karena kepercayaannya. Tuhan memakai umat-Nya untuk menyelamatkan Rahab dan menyatakan anugerah-Nya yang besar dan akhirnya Rahab dapat menerima keselamatan. Namun hal ini menjadi tidak biasa, karena status Rahab yang adalah bangsa non-Israel.

Bangsa Israel menjadi bangsa yang istimewa karena Allah mengikat perjanjian kepada mereka. ${ }^{88}$ Allah akan menyertai bangsa Israel serta membawa mereka ke tanah perjanjian (Kel. 6:3-7). Umat Israel menjadi umat pilihan Allah yang sejak semula telah mengikat janji dengan Allah. Hal ini, seolah-olah menunjukkan bangsa lain tidak masuk hitungan. Berkat pimpinan, penyertaan serta perlindungan hanya akan diperoleh oleh umat-Nya yang setia kepada Tuhan. Namun, berbeda dengan Rahab yang adalah orang Kanaan, tapi beroleh perlindungan dan keselamatan.

${ }^{88}$ Denis Green, Pembimbing Pada Pengenalan Perjanjian Lama (Malang: Gandum Mas, n.d.), 76 . 
Bangsa di luar Israel yang sepertinya tidak masuk hitungan, dapat beroleh berkat perlindungan dari Allah melalui umat-Nya.

Keselamatan yang diperoleh Rahab memang pantas untuk diterimanya. Rahab mengakui bahwa kengerian akan Allah Israel dan umat-Nya telah menghantui orang-orang Kanaan, bahkan Rahab juga merasakan ketakutan (Yos. 2:9-11). Tetapi tindakan yang Rahab ambil berbeda dengan orang Kanaan lain. Rahab menaruh percayanya kepada Allah dengan menolong kedua pengintai yang Yosua utus untuk mengintai. ${ }^{89}$ Layaklah Rahab memperoleh perlindungan, meskipun dirinya adalah bangsa non-Israel. Dari hal ini, anugerah Allah yang melampaui segala akal dapat terlihat. Rahab yang bukanlah orang Israel juga diizinkan untuk memperoleh perlindungan, bahkan keluarganya juga beroleh keluputan dari kematian. Kasih dan anugerah Allah berlaku bagi Rahab dan keluarganya yang berlatarbelakang bangsa Kanaan. Demikianlah peristiwa ini membuktikan bahwa keselamatan itu berlaku bagi siapa saja.

Keselamatan tidaklah diperuntukkan untuk orang-orang, suku-suku atau kalangan tertentu. Keselamatan dapat diterima oleh siapa saja yang rela dan mau menerimanya. Seperti Rahab, keselamatan dan perlindungan Allah akan dinikmati oleh orang-orang yang berani mengambil langkah untuk memercayai Allah. Oleh sebab itu, setiap orang percaya harus memiliki pemahaman bahwa keselamatan untuk semua orang. Tidaklah dinikmati oleh orang-orang tertentu saja, namun semua orang dapat menikmatinya dan keselamatan tersebut ada di dalam Yesus Kristus.

Keselamatan yang sejati hanya terdapat di dalam Yesus Kristus yang sudah berkorban bagi umat manusia. Melalui pengorbanan-Nya di kayu salib, setiap orang yang percaya akan beroleh pengampunan dosa dan keselamatan. Sebagai orang-orang percaya, sudah sepatutnya ucapan syukur diberikan bagi Allah yang melimpahkan rahmat-Nya. Status sebagai manusia lemah membuat kita tidak dapat menyelamatkan diri sendiri. Namun, Allah yang limpah akan rahmat menganugerahkan keselamatan kepada setiap orang yang percaya (Yoh. 3:16). Oleh sebab itu, ucapan syukur dan memuji Tuhan harus selalu meluap dari hati. Kehidupan orang Kristen harus dipenuhi dengan ucapan syukur karena oleh kesadaran akan anugerah Allah. Melalui anugerah Allah, manusia beroleh keselamatan. Melalui karya keselamatan yang dikerjakan Allah melalui Yesus Kristus, manusia dibenarkan. Kehidupan yang dipenuhi dengan rasa syukur menunjukkan bahwa pribadi tersebut sadar akan anugerah Allah dalam hidupnya dan wujud penghormatan kepada Allah Yang Mahakuasa dan Mahapengasih.

${ }^{89}$ John F. Walvoord dan Roy B. Zuck, ed., The Bible Knowledge Commentary (United States of America: Victor Books, 1985), 331. 
Selain rasa syukur, ketaatan dan kesetiaan juga patut kita junjung tinggi. Keselamatan yang diperoleh karena anugerah juga membawa setiap orang percaya untuk sadar bahwa hanya anugerah orang-orang Kristen bisa hidup. Kesadaran ini seharusnya membawa setiap orang percaya untuk lebih setia dan tidak jemu-jemu melakukan kehendak Tuhan. Manusia diciptakan untuk memuliakan Tuhan dan diwujudkan dengan melakukan kehendak-Nya, bukan melakukan kehendaknya sendiri..$^{90}$

Selain ucapan syukur dan kesetiaan, keselamatan bagi setiap orang merupakan sebuah kabar gembira dan setiap orang perlu mendengarnya. Oleh sebab itu, kabar sukacita ini harus diberitakan kepada semua orang. Setiap orang perlu tahu bahwa kasih Allah diperuntukkan bagi siapa saja yang mau menerimanya. Keselamatan terbuka bagi siapa saja. Oleh sebab itu, setiap orang Kristen perlu memberitakan kabar keselamatan kepada banyak orang yang belum mendengarkan kabar tersebut.

\section{Jangan Menghakimi}

Tidak dapat dipungkiri, Rahab memberikan pertolongan dengan sungguh-sungguh kepada kedua utusan Yosua. Rahab menolong kedua pengintai dengan serius, bahkan ia menggunakan kebohongan untuk menolong mereka. Sesuatu hal yang dipandangan manusia tindakan buruk dan tidak pantas, namun Rahab melakukannya demi menolong kedua pengintai. Namun, penulis percaya bahwa dalam tatanan rencana Allah, tindakan yang dipandang buruk atau "kotor", Tuhan pakai untuk menolong umat-Nya. Melalui tindakan-tindakannya, Rahab menunjukkan kasih dan setianya kepada kedua pengintai, bahkan melalui kebohongannya. ${ }^{91}$ Demikianlah dalam rencana-Nya, Allah dapat mempergunakan apapun dan siapapun untuk memuliakan nama-Nya.

Seringkali orang percaya diperhadapkan dengan dua pilihan yang berat, antara jujur atau berbohong. Jika berbohong - secara moral tentu tidak baik - orang tersebut menyelamatkan atau menolong saudaranya. Tetapi jika jujur - secara moral baik - orang tersebut harus merelakan saudaranya untuk menerima hukuman. Kecenderungan beberapa orang adalah berbohong, tetapi tidak sedikit juga yang rela untuk bersikap jujur. Sedangkan, jika ada yang tahu tindakan tersebut adalah bohong, maka mereka cenderung menghakimi bahwa apa yang dilakukannya salah, padahal bisa jadi Allah memakai tindakannya untuk menolong saudaranya dan bisa jadi hal tersebut akan membawa perubahan kehidupan bagi orang yang ditolong.

\footnotetext{
${ }^{90}$ Stephen Tong, "Mengapa Kita Memuliakan Allah | SOTeRI - Situs Teologia Reformed," SABDA, diakses 20 Juli 2017, http://reformed.sabda.org/node/112.

${ }^{91}$ D. C. Mulder, Tafsiran Alkitab: Kitab Yosua (Jakarta: BPK Gunung Mulia, 2015), 22.
} 
Melalui kisah ini, penulis ingin menyoroti sikap menghakimi. Seringkali, beberapa orang terlalu cepat menghakimi sikap saudara seiman. Mendengar tindakan atau perbuatan orang lain yang aneh, tidak sepatutnya, atau tidak baik dalam pandangannya, mereka langsung saja menghakimi orang tersebut. Sebagai orang Kristen, sepatutnya janganlah terlalu cepat menghakimi dan menyalahkan tindakan seseorang. Sebagai orang percaya, jangan kita menghakimi tindakan seseorang yang dalam pandangan kita salah atau yang menurut pandangan kalangan umum itu salah.

Yesus Kristus mencela orang yang menghakimi orang lain. Meskipun dalam konteks yang berbeda, namun inti dari yang disampaikan Yesus dalam Matius 7:1-5 adalah sama, yaitu tentang larangan untuk menghakimi. Yesus tidak mau murid-muridnya saat itu menghakimi orang lain agar tidak dihakimi (ay. 1). Oleh sebab itu, janganlah kita terlalu cepat menghakimi perbuatan orang lain. Terkadang, Tuhan memakai perbuatan tersebut untuk menolong umat-Nya dan supaya nama Tuhan dipermuliakan seperti halnya dalam kisah Rahab.

\section{Mengasihi "Musuh"}

Rahab, seorang perempuan Kanaan dan wanita sundal, dapat Tuhan pakai untuk menyelamatkan kedua pengintai dalam menjalankan tugas mereka demikian juga siapa pun dapat Tuhan pakai untuk menolong umat-Nya saat ini. Pastinya kedua pengintai tidak sadar bahwa yang akan menolong mereka selama mengintai Yerikho adalah seorang perempuan sundal. Tuhan memakai Rahab untuk menolong kedua pengintai dalam menjalankan tanggung jawabnya. Tidak lain halnya orang percaya saat ini.

Allah dapat memakai siapa saja untuk menolong umat-Nya dalam menjalankan tugas tanggung jawab atau ketika diperhadapkan pada tantangan. Orang-orang yang tidak dipikirkan sebelumnya atau yang bahkan tidak masuk hitungan, Tuhan dapat pakai untuk menolong anakanak-Nya dalam menjalankan tugas ataupun ketika berada di tengah persoalan. Tuhan memakai Rahab, yang statusnya adalah seorang Kanaan - yang menjadi "musuh Allah" karena tindakan mereka yang bejat - untuk menyelamatkan kedua pengintai. Seseorang yang dipandang musuh oleh bangsa Israel, malahan Tuhan pakai untuk menjadi penyelamat dalam menjalankan misi mereka.

Dalam Matius 5:44 mencatatkan perkataan Yesus yang mengajak pendengarnya untuk mengasihi musuh dan berdoa bagi mereka. Yesus menghendaki orang-orang percaya untuk mengasihi siapa saja, bahkan musuh. Tuhan punya kuasa dan kedaulatan untuk memakai siapapun demi menolong anak-anak-Nya, bahkan orang yang dipandang sebagai musuh sekalipun. 


\section{Kesimpulan}

Penulis Surat Yakobus dan Surat Ibrani menyatakan bahwa Rahab diselamatkan karena imannya. Iman Rahab diwujudkan melalui tindakan Rahab kepada kedua pengintai. Berdasarkan pembahasan tentang kepercayaan Rahab dari Yosua 2, kesimpulan yang dapat diambil adalah setiap tindakan Rahab memanglah menunjukkan akan kepercayaannya kepada Allah. Seluruh tindakan Rahab di dalam Yosua 2 menunjukkan bahwa ia menaruh kepercayaan kepada Tuhan Allah bangsa Israel. Tindakan-tindakan Rahab meliputi: menerima kedua pengintai (ay. 1), melindungi kedua pengintai (ay. 2-7), pengakuannya (ay. 9-11), permintaan (ay. 12-13), menolong kedua pengitnai kabur (ay. 15-16) dan merespons serius dan segera setiap perjanjiannya dengan kedua pengintai (ay. 17-21).

Selain itu, melalui pembahasan tentang kepercayaan Rahab, ada beberapa poin penting yang dapat menjadi implikasi bagi kehidupan orang percaya masa kini. Pertama, kepercayaan menuntut pengakuan dan tindakan. Iman kepercayaan tidak hanya melalui pengakuan dari mulut saja. Kepercayaan juga diwujudkan melalui tindakan dan ketaatan orang percaya melakukan Firman Tuhan. Pengakuan dan tindakan tidaklah dapat dipisahkan. Kedua, keselamatan diperuntukkan bagi semua orang yang percaya. Keselamatan tidak diperuntukkan bagi pribadi, kelompok, atau suku dan budaya tertentu. Keselamatan berhak dinikmati oleh semua orang yang percaya kepada Yesus Kristus. Ketiga, janganlah menghakimi tindakan orang lain. Jangan cepat mempersalahkan atau menghakimi tindakan orang yang menurut pandangan umum atau pribadi kita tidak benar atau tidak cocok. Allah dapat memakai tindakan tersebut untuk menolong umat-Nya bahkan mempermuliakan nama-Nya. Keempat, mengasihi orang yang dipandang sebagai musuh. Perbedaan suku, budaya, karakter atau agama, tidak boleh menutup pintu kasih dalam diri kita. Kasih harus dinyatakan kepada siapapun, bahkan kepada orang yang dipandang sebagai "musuh". Tuhan dapat memakai orang yang kita pandang musuh dan bahkan "tidak masuk hitungan" untuk menolong anak-anak-Nya.

\section{Kepustakaan}

Alkitab Terjemahan Baru. Jakarta: Lembaga Alkitab Indonesia, 2002.

Andrews, Edgar. A Glorious High Throne. England: Evangelical Press, 2009.

Bakker, F. L. Sejarah Kerajaan Allah 1: Perjanjian Lama. Jakarta: BPK Gunung Mulia, 2004 
Carson, D. A., R. T. France, J. A. Motyer, G. J. Wenham, ed. New Bible Commentary. England: Inter-Varsity Press, 1995.

Currid, John D. Strong and Courageous: Joshua Simply Explained. England: EP Books, 2011.

Darmaputera, Eka. Imamat Yang Sempurna. Jakarta: BPK Gunung Mulia, 2012.

Darmaputra, E. Iman Dalam Perbuatan. Jakarta: BPK Gunung Mulia, 2012.

Douglas, J. D. ed. Ensiklopedi Alkitab Masa Kini Jilid 2: M-Z. Jakarta: Yayasan Komunikasi Bina Kasih /OMF.

Epp, Theodore H. Joshua - Victorious by Faith. Nebraska: Back To The Bible Broadcast, 1968.

Gaebelein, Frank E. ed. The Expositor's Bible Commentary. Michigan: Zondervan Publishing House, 1992.

Gooding, David. An Unshakeable Kingdom. Michigan: William B. Eerdmans Publishing Company.

Green, Denis. Pembimbing Pada Pengenalan Perjanjian Lama. Malang: Gandum Mas.

Guthrie, Donald, Alec Motyer, Alan M. Stibbs, Donald J. Wiseman. Tafsiran Alkitab Masa Kini l: Kejadian - Ester. Jakarta: Yayasan Komunikasi Bina Kasih, 2015.

Harlow, R. E. Winning e Losing: Studies in Joshua, Judges, Ruth. Canada: Everyday Publication Inc., 1984.

Harrison, R. K. Old Testament Times. Michigan: William B. Eerdmans Publishing Company, 1979.

Holdcroft, L. Thomas. Kitab-Kitab Sejarah. Malang: Gandum Mas, 1996.

Kee, Howard Clark, David G. Burke, Steven W. Berneking, dan Errol F. Rhodes, ed. Alkitab Edisi Studi. Jakarta: Lembaga Alkitab Indonesia, 2015.

Lasor, W. S., D. A. Hubbard, dan F. W. Bush. Pengantar Perjanjian Lama 1: Taurat dan Sejarah. Jakarta: BPK Gunung Mulia, 1993.

Louterboom, Mariska. "Pelacuran Suci: Konsep Pelacuran Menurut Kisah Perempuan Bernama Rahab dalam Yosua 2:1-24 sebagai bagian Sejarah Deuteronomis." Jurnal Kajian Sosial Interdisipliner Bina Darma 24, No. 72 (September 2006): 209-226.

Mulder, D. C. Tafsiran Alkitab: Kitab Yosua. Jakarta: BPK Gunung Mulia, 2015.

Park, Abraham. Pelita Perjanjian Yang Tak Terpadamkan. Jakarta: Grasindo, 2012.

Ryken, Leland, James C. Wilhoit, Tremper Longman III, ed. Kamus Gambaran Alkitab: The Dictionary of Biblical Imagery. Surabaya: Momentum, 2011. 
Scheunemann, Rainer. Surat Yakobus. Jayapura: Sekolah Tinggi Teologi "I. S. Kijne," 2005.

Stamps, Donald C., ed. Alkitab Penuntun Hidup Berkelimpahan. Malang: Gandum Mas, 2010.

"The Conquest of the Promised Land: Joshua - Ibiblio." Diakses 21 Juni

2017. www.ibiblio.org/freebible commentary/pdf/EN/VOL04OT.pdf. Tong, Stephen. "Mengapa Kita Memuliakan Allah | SOTeRI - Situs

Teologia Reformed," SABDA. Diakses 20 Juli 2017. http://reformed.sabda.org/node/1l2.

Walvoord, John F. dan Roy B. Zuck, ed. The Bible Knowledge Commentary. United States of America: Victor Books, 1985. 